\title{
32. SUMMARY OF CHERT OCCURRENCES FROM LINE ISLANDS SITES 314, 315, 316 DSDP LEG 33
}

\author{
Kerry Kelts, Geological Institute ETH, Swiss Federal Institute of Technology, 8006 Zurich, Switzerland
}

\begin{abstract}
This chapter summarizes cherts recovered in calcareous and clayey sediments at subbottom depths from 45 to 990 meters ranging from lowermost Miocene (NN1) to Santonian age. Gray nodules are most common in Oligocene chalks, bedded red-brown and brown cherts in Eocene chalks and limestones, and olive-green to brown nodules in Upper Cretaceous claystones and clayey limestones. Tertiary cherts contain both quartz and cristobalite phases, whereas Cretaceous varieties appear slightly more quartzitic. Progressive structural development was observed in alpha-cristobalite lepispheres. Numerous textural variations result from the chertification of different lithologic types, reflecting the influence of sediment redeposition and burrowing activity. Stratigraphic anomalies are puzzling, but the occurrences best fit a model of biogenic-silica-derived solutions precipitating an initial cristobalite phase followed by the rapid or slow conversion to pure quartzose cherts depending on the host lithology.
\end{abstract}

\section{INTRODUCTION}

Theories of chert formation have progressed considerably since the nostalgic days of ignorance about deep-sea sediments. At that time, some theories, which now appear exotic, predicted that lumpy chert formed directly on the ocean floor by the coagulation of the silicic acid sol into a hydrogel which then contracted into a concentric chert nodule (Taliaferro, 1934). The vast number of cores now available from the sea bottom have produced no silica gels, but the controversy about the mechanics of chert formation still rages. It must first be remembered that chert, as used in this and many other papers, is a collective name for a variety of siliceous sediments which may show heterogeneous mineralogy, textures, and development. A number of excellent papers presenting new ideas and reviewing the modes of chert occurrences have recently appeared. Most authors (Heath and Moberly, 1971; Heath, 1974; Von Rad and Rösch, 1974; Calvert, 1974; Wise and Weaver, 1974) favor a model in which biogenic silica is dissolved, cristobalite is precipitated and then matures to quartzose chert. An alternative model suggests that lithology is the controlling factor and quartz precipitates directly in calcareous sediments whereas cristobalite is dominant in clay-rich sediments (Lancelot, 1973). Silica input from volcanic sources could also be significant.

Chert formation remains an enigma partly because most theories imply that chert should be even more abundant than now known. Why is any of the biogenic silica preserved at all? When does chert form? What are the initial silica phases? What controls the kinetics? Answers to these and other questions await more experimental data and continuation of efforts to compile a record of observations based on deep sea drilling.
The scope of this chapter is limited to briefly summarizing the cherts recovered from Sites 314,315 , and 316 drilled along the Line Islands Seamount chain. DSDP participants have been generally impressed by the wide variety of textural and lithological features resulting from the silicification of deep-sea sediments. Thus, some aspects are illustrated and discussed which may be pertinent to the chert problem. Terminology follows the usage of several previous authors (Heath, 1974; Lancelot, 1973; Wise and Weaver, 1974).

\section{GEOLOGY}

The varieties of cherts recovered in the archipelagic sediments of the Line Islands chain show many of the features and trends previously observed by Heath and Moberly (1971), Lancelot (1973), and Heath (1973) in their studies of cherts from the lower latitudes of the Central Pacific region. Table 1 summarizes the occurrences of silicified sediment recovered as discrete nodules or sections from apparent chert beds. We similarly observed that gray nodular varieties are most common in calcareous chalk sequences, in particular of Oligocene age. The apparently bedded varieties show little resemblance to their land-based counterparts and are mostly confined to Eocene chalks and limestones. Olivegray to brown nodules are sporadic in clay-rich Cretaceous sediments. The lack of correlation of chert beds based on lithologic character between Sites 316 and 315 suggests that silicification processes are of limited areal extent.

The youngest chert recovered is a gray porcellanitic nodule (315A-8-3, 58-67 cm; $592 \mathrm{~m})$ in nanno-chalks of lowermost Miocene age. Surprisingly, in thin section, much of the sample contains patches of barite (celestite?) intermeshed with very fine grained chalcedony as the cementing agents. Celestite is indicated by chemical 
TABLE 1

Summary of the Cherts Recovered from the Line Islands Sites 314,315 , and 316

\begin{tabular}{|c|c|c|c|c|}
\hline $\begin{array}{c}\text { Sample } \\
\text { (Interval in } \mathrm{cm} \text { ) }\end{array}$ & $\begin{array}{l}\text { Depth } \\
\text { (m) }\end{array}$ & Age & Host Lithology & Description \\
\hline $315 \mathrm{~A}-8-3,58-67$ & 591 & $\begin{array}{l}\text { U. Oligocene/ } \\
\text { lower Miocene }\end{array}$ & Chalk & $\begin{array}{l}\text { Medium dark gray porcellanite chert } \\
\text { nodule containing celestite (barite?) as } \\
\text { cement and as olive-gray specks around } \\
\text { the nodule border }\end{array}$ \\
\hline $315 \mathrm{~A}-9, \mathrm{CC}$ & 712.5 & M. Oligocene & Chalk & $\begin{array}{l}\text { (1) Pale brown porcellanite nodule with } \\
\text { light gray rim; ( } 2 \text { ) Greenish-gray hard } \\
\text { siliceous nannofossil chalk with faint } \\
\text { lamination }\end{array}$ \\
\hline $315 \mathrm{~A}-10-1,4-8$ & 732 & L. Oligocene & Chalk & $\begin{array}{l}\text { Very light gray cherty zone with a sharp } \\
\text { lower contact and diffuse, irregular upper } \\
\text { transition }\end{array}$ \\
\hline $315 \mathrm{~A}-10-1,60-69$ & 733 & L. Oligocene & $\begin{array}{l}\text { Light greenish- } \\
\text { gray chalk }\end{array}$ & $\begin{array}{l}\text { Various porcellanite nodules including: } \\
\text { (1) light gray with a center of preserved } \\
\text { chalk; (2) various gray chert fronts with } \\
\text { unreplaced burrow traces; }(3) \text { gray with } \\
\text { disrupted bedding }\end{array}$ \\
\hline $315 \mathrm{~A}-10-2,10-14$ & 733.5 & L. Oligocene & Chalk & $\begin{array}{l}\text { Gray nodular fragments with remnant } \\
\text { white specks and preserved burrows }\end{array}$ \\
\hline $315 \mathrm{~A}-10-2,35-43$ & 733.5 & L. Oligocene & Chalk & $\begin{array}{l}\text { Silicified grainstone with scattered pala- } \\
\text { gonite fragments outlining laminations; } \\
\text { patchy gray replacement with white } \\
\text { specks }\end{array}$ \\
\hline $\begin{array}{l}315 \mathrm{~A}-10-3,95-110 \\
315 \mathrm{~A}-10-3,95-142\end{array}$ & 736 & U. Eocene & $\begin{array}{l}\text { Redeposited } \\
\text { chalks and } \\
\text { limestones }\end{array}$ & $\begin{array}{l}\text { Light gray to medium blue-gray nodules } \\
\text { and reddish-brown chert replacing fine to } \\
\text { coarse sand layers in varying degrees; } \\
\text { laminations, palagonite grains, and undi- } \\
\text { gested chalk patches }\end{array}$ \\
\hline $315 \mathrm{~A}-10-4,47-51$ & 737 & Eocene & $\begin{array}{l}\text { Light olive- } \\
\text { gray clayey } \\
\text { nanno chalk }\end{array}$ & As above \\
\hline $315 \mathrm{~A}-11-1,110-150$ & 749 & Eocene & $\begin{array}{l}\text { Claystone } \\
\text { Chalk (?) }\end{array}$ & $\begin{array}{l}\text { (1) Dark yellowish-brown laminated } \\
\text { cherty claystone; scattered halos of } \\
\text { greenish gray along fractures; ( } 2 \text { light } \\
\text { gray, silica replacement of a fuccoid } \\
\text { chalk (3) yellowish-brown cherty foram } \\
\text { grainstone with white specks, lamina- } \\
\text { tions, and a discordant gray quartz vein }\end{array}$ \\
\hline $315 \mathrm{~A}-11, \mathrm{CC}$ & 749 & Eocene & Chalk (?) & $\begin{array}{l}\text { Various fragments of brown, reddish- to } \\
\text { yellowish-brown chert replacing fine- } \\
\text { grained sandy carbonates, some with } \\
\text { laminations and vague current structures; } \\
\text { all specimens show patchy remnant cal- } \\
\text { cite and are cut discordantly by quartz } \\
\text { (chalcedony) veins }\end{array}$ \\
\hline $315 \mathrm{~A}-12, \mathrm{CC}$ & 759 & Eocene & $?$ & $\begin{array}{l}\text { Brownish-black to dusky yellowish- } \\
\text { brown brecciated chert; numerous micro- } \\
\text { faults showing brittle fracture, various } \\
\text { inclusions of partially undigested pink } \\
\text { chalk and cut by quartz veins }\end{array}$ \\
\hline $315 \mathrm{~A}-14, \mathrm{CC}$ & 778 & $\begin{array}{l}\text { Eocene/ } \\
\text { Paleocene }\end{array}$ & $?$ & $\begin{array}{l}\text { Red chert replacement of a well-bedded } \\
\text { grainstone, cut by a thick ( } 5 \mathrm{~mm}) \text { quartz } \\
\text { vein; spheroid inclusions are white chalk } \\
\text { and reddish-orange earthy sediment; pre- } \\
\text { served foram specks are concentrated } \\
\text { upward }\end{array}$ \\
\hline $315 \mathrm{~A}-15-1,46-48$ & 780 & U. Paleocene & $\begin{array}{l}\text { Nanno } \\
\text { claystone }\end{array}$ & $\begin{array}{l}\text { Olive-black to gray nodular cherts and } \\
\text { reddish-brown siliceous grainstone }\end{array}$ \\
\hline $315 \mathrm{~A}-15-2,90-150$ & 781 & U. Paleocene & $\begin{array}{l}\text { Brown-black } \\
\text { claystone }\end{array}$ & Olive-gray to black chert nodule \\
\hline $315 \mathrm{~A}-16-1,90-150$ & 788 & M. Maestrichtian & $\begin{array}{l}\text { Clayey } \\
\text { limestone }\end{array}$ & $\begin{array}{l}\text { Dusky yellow-brown silicified claystone } \\
\text { and a brown incompletely silicified grain- } \\
\text { stone }\end{array}$ \\
\hline
\end{tabular}


TABLE 1 - Continued

\begin{tabular}{|c|c|c|c|c|}
\hline $\begin{array}{c}\text { Sample } \\
\text { (Interval in } \mathrm{cm} \text { ) }\end{array}$ & $\begin{array}{l}\text { Depth } \\
\text { (m) }\end{array}$ & Age & Host Lithology & Description \\
\hline $315 \mathrm{~A}-16-2,55-56$ & 790 & M. Maestrichtian & $\begin{array}{l}\text { Styolitic white } \\
\text { limestone with } \\
\text { red seams }\end{array}$ & $\begin{array}{l}\text { Patchy reddish-brown chert incompletely } \\
\text { replacing a very pale orange foram grain- } \\
\text { stone }\end{array}$ \\
\hline $315 \mathrm{~A}-17-1,140-142$ & 798 & M. Maestrichtian & $\begin{array}{l}\text { White micrite } \\
\text { limestone }\end{array}$ & $\begin{array}{l}\text { Dusky yellow-brown concretionary chert } \\
\text { nodule }\end{array}$ \\
\hline $315 \mathrm{~A}-18-1,113-116$ & 808 & L. Maestrichtian & Limestone & $\begin{array}{l}\text { Brown irregular nodule with a pale green } \\
\text { halo }\end{array}$ \\
\hline $315 \mathrm{~A}-18-2,53$ & 808.5 & L. Maestrichtian & $\begin{array}{l}\text { Redeposited } \\
\text { limestone }\end{array}$ & Brown nodule \\
\hline $315 \mathrm{~A}-18-4,21-22$ & 812 & L. Maestrichtian & Foram grainstone & Dark eyllowish-brown nodule \\
\hline $315 \mathrm{~A}-21-3,21-22$ & 840 & U. Campanian & Clayey limestone & $\begin{array}{l}\text { Minor patches of red-brown chert in } \\
\text { redeposited bed }\end{array}$ \\
\hline $315 \mathrm{~A}-24-2,19-25$ & 877 & M. Campanian & $\begin{array}{l}\text { Light gray lime- } \\
\text { stone and volcan- } \\
\text { ogenic turbidites }\end{array}$ & $\begin{array}{l}\text { Red-brown nodule with small patches of } \\
\text { undigested pink limestone }\end{array}$ \\
\hline $315 \mathrm{~A}-28-3,80-85$ & 955 & Santonian (?) & $\begin{array}{l}\text { Variegated vol- } \\
\text { canogenic } \\
\text { sediments }\end{array}$ & $\begin{array}{l}\text { Greenish-black to blue-green chert } \\
\text { (quartz) nodule }\end{array}$ \\
\hline $316-5-1,1-107$ & 449 & L. Oligocene & Chalk & $\begin{array}{l}\text { Pale yellow brown porcellanite with } \\
\text { unreplaced specks of foraminifers }\end{array}$ \\
\hline $\begin{array}{l}316-5-2,130-132 \\
316-5-2,120-122\end{array}$ & 451 & M. Eocene & Chalk & $\begin{array}{l}\text { Pale yellow-brown porcellanite; distribu- } \\
\text { tion and shape of undigested chalk sug- } \\
\text { gests that burrows were silicified last }\end{array}$ \\
\hline $316-5, \mathrm{CC}$ & 451 & M. Eocene & Chalk & $\begin{array}{l}\text { Irregular silicification of a pale orange } \\
\text { nanno chalk by moderately brown chert; } \\
\text { the host limestone around the chert is } \\
\text { devoid of siliceous fossils }\end{array}$ \\
\hline $316-6, \mathrm{CC}$ & 457 & M. Eocene & Chalk & $\begin{array}{l}\text { Irregular patch of yellow-brown chert in } \\
\text { white siliceous chalk }\end{array}$ \\
\hline $\begin{array}{l}316-7-1,137-138 \\
316-7-2,0-10\end{array}$ & 466 & M. Eocene & Chalk & $\begin{array}{l}\text { Reddish-brown chert with pinky orange } \\
\text { chalk inclusions }\end{array}$ \\
\hline $316-8-1,130-134$ & 477 & L.-M. Eocene & Hard chalk & Dusky brown chert \\
\hline $316-8-1,140-145$ & 477 & L.-M. Eocene & Limestone & $\begin{array}{l}\text { Light brown chert nodule with center of } \\
\text { pink-orange dolomitic limestone }\end{array}$ \\
\hline $316-8, \mathrm{CC}$ & 477 & L.-M. Eocene & ? & $\begin{array}{l}\text { Brown to yellow-brown chert with sur- } \\
\text { face coatings of "Mn"-dendrites, quartz } \\
\text { veins and laminations (see Figure 4) }\end{array}$ \\
\hline $\begin{array}{l}316-9-1,0-36 \\
316-9-1,78-84 \\
316-9-1,130-150 \\
316-9, \text { CC }\end{array}$ & 486 & L.-M. Eocene & $\begin{array}{l}\text { Redeposited } \\
\text { limestone grain- } \\
\text { stones; brown } \\
\text { dolomite }\end{array}$ & $\begin{array}{l}\text { Dark gray to dusky brown and pale red } \\
\text { chert with orange residual chalk patches, } \\
\text { white specks, and the greenish outlines } \\
\text { of forams }\end{array}$ \\
\hline $\begin{array}{l}316-10-1,22-55 \\
316-10-1,-85-80 \\
316-10-1,100-120\end{array}$ & 496 & L. Eocene & $\begin{array}{l}\text { Hard foram- } \\
\text { nanno chalk }\end{array}$ & $\begin{array}{l}\text { Various fragments varying from reddish- } \\
\text { brown and brown to one olive-brown; } \\
\text { foram chambers filled with chalcedony }\end{array}$ \\
\hline $316-11-1$ & 514 & Paleocene & Hard chalk & $\begin{array}{l}\text { Light gray to medium gray chert layers } \\
\text { with relict bedding and undigested white } \\
\text { specks; chalcedony in foram chambers } \\
\text { and in the matrix }\end{array}$ \\
\hline $\begin{array}{ll}316-12-2, & 60-63 \\
316-12-2, & 85-90 \\
316-12-2 ; & 107-110 \\
316-12-2, & 134-136\end{array}$ & 524 & Paleocene & $\begin{array}{l}\text { Micrite } \\
\text { claystone }\end{array}$ & Brown to gray chert fragments \\
\hline $316-13,30-40$ & 534 & Paleocene & Limestone & Reddish-brown chert \\
\hline $\begin{array}{l}316-14-1,25-26 \\
316-14-1,105-110 \\
316-14-1,142-148\end{array}$ & 543 & Paleocene & Limestone & $\begin{array}{l}\text { Reddish-brown chert as nodules, ovoid } \\
\text { blebs and zoned halos around what may } \\
\text { be possibly former burrows }\end{array}$ \\
\hline
\end{tabular}


TABLE 1 - Continued

\begin{tabular}{|c|c|c|c|c|}
\hline $\begin{array}{c}\text { Sample } \\
\text { (Interval in } \mathrm{cm} \text { ) }\end{array}$ & $\begin{array}{l}\text { Depth } \\
(\mathrm{m})\end{array}$ & Age & Host Lithology & Description \\
\hline $\begin{array}{l}316-15-1,88-92 \\
316-15-1,105-110\end{array}$ & 553 & Paleocene & Limestone (?) & Dark reddish-brown chert, massive \\
\hline $\begin{array}{l}316-16-1,25-30 \\
316-16-1,60-65\end{array}$ & 562 & Paleocene & $\begin{array}{l}\text { Foram-nanno } \\
\text { chalk }\end{array}$ & $\begin{array}{l}\text { Dark reddish-brown chert replacing gray- } \\
\text { ish-pink chalk limestone. Several con- } \\
\text { centric zones suggest an advancing front }\end{array}$ \\
\hline $\begin{array}{l}316-16-2,22-28 \\
316-16-2,108-117\end{array}$ & 563 & Paleocene & $\begin{array}{l}\text { Foram-nanno } \\
\text { chalk }\end{array}$ & As above \\
\hline $\begin{array}{l}316-17-1,100-104 \\
316-17-1,135 \\
316-17-1,137-144\end{array}$ & 572 & Paleocene & Hard chalk & Red chert with preserved volcanic grains \\
\hline $\begin{array}{l}316-18-1,103-106 \\
316-18-1,80-85\end{array}$ & 592 & M. Maestrichtian & Limestone & $\begin{array}{l}\text { Grayish-olive-green, homogeneous chert } \\
\text { nodules }\end{array}$ \\
\hline $316-18-3,50-58$ & 595 & M. Maestrichtian & $\begin{array}{l}\text { Silicified } \\
\text { limestone }\end{array}$ & $\begin{array}{l}\text { Red chert with replaced forams and hori- } \\
\text { zontal laminations }\end{array}$ \\
\hline $316-22-3,103-106$ & 651 & $\begin{array}{l}\text { M. Maestrichtian } \\
\text { to U. Campanian }\end{array}$ & Clayey limestone & $\begin{array}{l}\text { Ovoid brown chert nodule with a silica- } \\
\text { depleted center of light colored micrite } \\
\text { limestone, interbedded in redeposited } \\
\text { volcanogenic sediments which extend } \\
\text { from } 580 \text { meters to } 837 \text { meters }\end{array}$ \\
\hline $314-3, \mathrm{CC}$ & 45 & Eocene (?) & $\begin{array}{l}\text { Brown zeolitic } \\
\text { clay to } \\
\text { claystone }\end{array}$ & $\begin{array}{l}\text { Light } \tan \text { to brown porcellanitic clay- } \\
\text { stone and porcellanite fragments }\end{array}$ \\
\hline
\end{tabular}

and X-ray analysis (R.E. Boyce, personal communication), but confirmation is difficult because the two minerals are very similar and barite can contain considerable $\mathrm{Sr}$ in solid solution. X-ray diffraction also indicates the presence of some cristobalite. Under crossed nicols the cement exhibits a uniform extinction pattern defining a preferred fabric.

The oldest chert recovered is a dark blue-green laminated nodule of presumedly Santonian age consisting of quartz, mica, and feldspar. This paragenesis in the midst of volcanogenic sediments might suggest a volcanic source of silica. However, the conclusion that silica may have been so derived is complicated by the presence of rare, heavily overgrown quartzose radiolarian remnants in immediately surrounding sediments. The most massive cherts, as expected, were recovered from the Eocene sections. Plugs up to $20 \mathrm{~cm}$ long were cored from presumably bedded cherts.

\section{Mineralogy}

Only 10 samples of cherts were examined by routine $\mathrm{X}$-ray analysis (Cook and Zemmels, this volume). Quartz is ubiquitous in all samples and in thin section is of the chalcedonic type. Opal-CT (Jones and Segnit, 1971 ) is present in some samples from both Tertiary and Cretaceous varieties but appears more prevalent in clayey lithologies. One Maestrichtian brown clay contains a pure quartz phase (315A-15-1, $132 \mathrm{~cm})$, whereas another (315A-16-1, $103 \mathrm{~cm})$ brown Maestrichtian nodule shows considerable cristobalite.

Conclusions as to the role of age or lithology can only be speculative, but a duality in which aging effects may be coupled with lithological character of the host sediment is suggested.

One of the puzzling questions which frequently arises in discussions of chert formation concerns the initially precipitated silica phase. Most authors now agree that biogenic sources are the most important silica suppliers through the mechanism of a solution step (Heath, 1974; Calvert, 1974; Wise and Weaver, 1974). Some suggest that quartz can be a primary precipitate (Lancelot, 1973; Heath and Moberly, 1971) while others believe that quartz phases are preceded by primary precipitation as alpha-cristobalite (opal-CT or lussatite) (e.g., Wise and Weaver, 1974; Von-Rad and Rösch, 1974), which matures into chalcedony and quartz.

In one of the scanning electron microscope studies for this report a slightly silicified, white foram-nanno grainstone was examined. X-ray analysis showed both quartz and some opal-CT as silica phases. Mineral compositions during SEM observation were checked with an energy-dispersive X-ray analysis attachment. The micrographs (Plate 1) show that several of the silica lepispheres (Wise and Kelts, 1972) found growing in the free space of a foram chamber had fortuitously been split in the middle, thus revealing a cross-sectional morphological development. Incipient phases show initially a seed core as an aggregate of visually, highly disordered silica about $1 \mu \mathrm{m}$ in diameter. Individual knobs in sections of this aggregate are less than $0.1 \mu \mathrm{m}$. This zone is followed by the transition to an interpenetrating mass of moderately well developed alpha-cristobalite sheaves. Along the outer edges, the blades are ragged and vermiform, suggesting that these are the sites of active nucleation. An examination of a thin section of this sample under crossed-nicols (Figure 1) shows that the initial silica lining within a foram chamber is pseudoisotropic. Under high magnification the seed core and rim of a lepisphere is isotropic whereas the bladed section has a faint birefringence. In this thinsection, which is typical for many others, some foram chambers are completely filled with apparently 


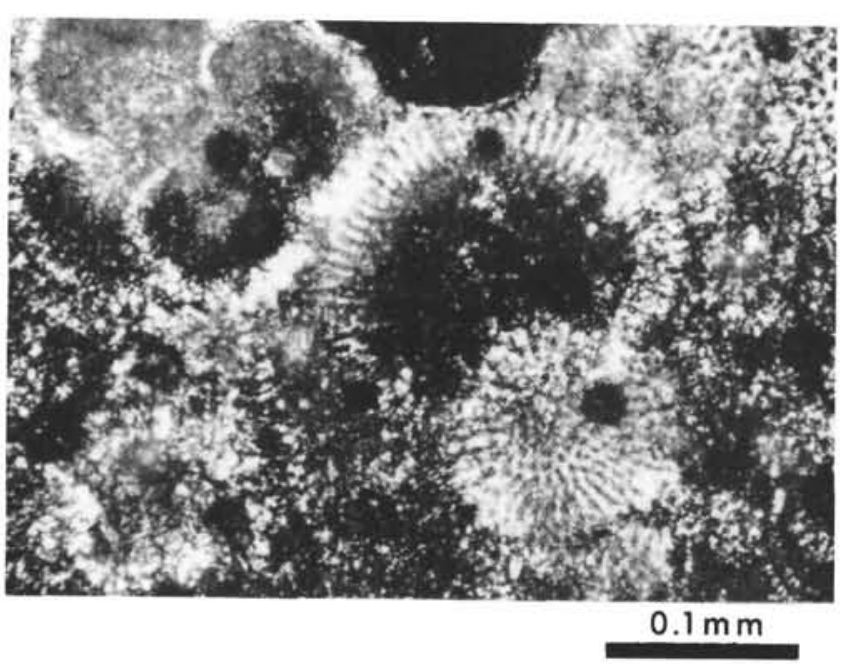

Figure 1. Sample 315A-10-2, 33-37 cm (733 m), lower Oligocene. Partially silicified redeposited, light greenishgray foram grainstone. Compare this thin-section micrograph with the same sample by SEM in Plate 1. Matrix and some foram shells partially replaced with cryptocrystalline silica. Some chambers infilled with chalcedony or micrite, others with an alpha-cristobalite lining. Crossednicols.

chalcedonic silica. This may be further evidence that initial alpha-cristobalite lepispheres invert to quartz.

Lepispheres of cristobalite are now considered common and have been illustrated in numerous recent reports (Lancelot, 1973; Matter, 1974; Weaver and Wise, 1972; and Wise and Weaver, 1974). A conspicuous characteristic observed in these examples is that lepispheres show size and morphological variations. Smaller varieties appear less well developed than others, reflecting a possible progressive development. Focused electron diffraction data from various regions would help delimit possible heterogeneous structural stages. The $10 \mu \mathrm{m}$ upper size limit commonly recorded might represent a critical size after which quartz phases are favored.

The paradox of stratigraphic anomalies in silicification of Eocene sediments is illustrated by Sample 315A10, CC (Figures 2a and b) from the same core as the above grainstone. Macroscopically, it is a light tan to pale orange-brown, burrowed, fucoidal, hard chalk. In thin section foraminifers are present mostly as recrystallized calcite with micrite fillings. Radiolarians are abundant and mostly unrecrystallized. Many radiolarian chambers are partially filled with lowbirefringent silica phases, and the matrix comprises about $50 \%$ apparently isotropic silica. Neither a silicification front nor much quartz is visible in these chalks, but a partial silicification of the matrix has taken place with apparently only selective destruction of radiolarian tests. As an explanation, Calvert (1974) has suggested that some siliceous fossils may be coated by compounds which act as a protective buffer.

Johnson (this volume) reports that radiolarians are well preserved in Quaternary to upper Oligocene sediments (0-598 m), highly corroded from upper Oligocene to upper Eocene $(602-740 \mathrm{~m})$, and disappear just below the samples from Core 10A discussed above. This correlation with the chert abundance again suggests the biogenic origin for silica in solution.

\section{TEXTURES}

Cherts recovered during Leg 33 display a wide variety of textures that may reflect differences in the mode of formation. Heath and Moberly (1971) have presented a clear account of the textures encountered in gray chert nodules associated with chalks that also apply to Leg 33 samples. Therefore, the discussion below is directed mainly towards the presumedly bedded cherts.

\section{Redeposited Sediments}

Graded or laminated redeposited sediments, commonly foram grainstones, are preferred sites of chertification, especially in the Eocene. Figure 3 illustrates a typical example of a silicification "front" recorded in a graded foram grainstone bed containing a few scattered palagonite grains. Diffusion halos of reddish-brown chert of progressive intensity encompass the matrix leaving a few relict calcite foraminifers as white pinpoints. In the darkest areas quartz is the main silica mineral. The selective replacement of a sample leaving foraminiferal relicts contrasts with some other samples in which the forams appear to have been replaced in the early stages of silicification.

\section{Burrowing}

Burrowing traces display diametric effects on chert textures. In many cases burrows act as ready conduits for solutions and are preferred sites of chertification. In others, burrows seem to inhibit the process and are commonly outlined as relict chalk patches (Figures 4 and 5). These textures probably reflect differences in permeability and microenvironment around burrow traces. The relict inclusions in cherts should help delimit the mechanisms of silica transfer. In many cases patches of relict chalks are completely depleted of many substances, in particular, silica. Figure 5 illustrates an orange-brown chert with chalk inclusions. Many have fuzzy outlines and a pink to orange earthy texture imparted by iron-oxide concentrations. Such samples imply that silicification slows or ceases once local silica supplies have been exhausted possibly after chert patches nucleating from different loci coalesce and reduce the permeability. In other cases the boundary between chert and an unsilicified inclusion is razor sharp.

\section{Brecciation}

Cherts showing brecciation and recementation textures are particularly common in the Eocene of the Line Islands sites. In some (e.g., 315A-12, CC) several interfering generations of brecciation are visible but still encompass irregular teardrop patches of relict chalk. Fibrous chalcedony generally fills fractures with fibers perpendicular to fracture surfaces. Translucent quartz veinlets up to $4 \mathrm{~mm}$ wide cut through a series of bedded reddish-brown cherts. The relative age and origin of these quartz veins are puzzling. Lancelot (1973) noted evidence indicating that brecciation and the filling of fractures with quartz may take place before compaction. 


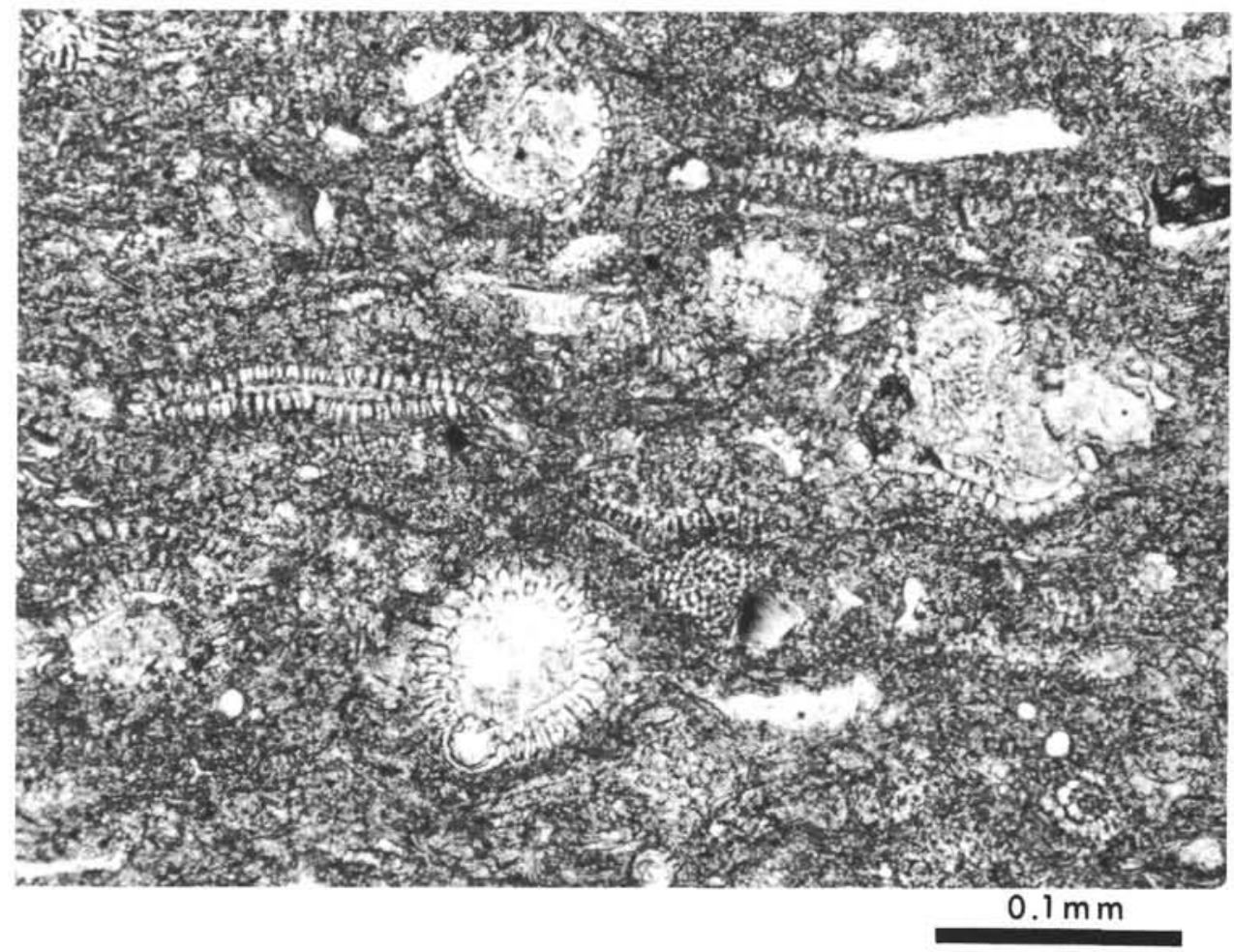

Figure 2a. Sample 315A-10, CC (737 m), Eocene. Thin-section micrograph of a partially silicified, tan to very pale orange, fuccoid, hard radiolarian-nannofossil chalk. Numerous apparently unrecrystallized radiolarians in a micritic calcite matrix. Compare to Figure 1 from the same core.

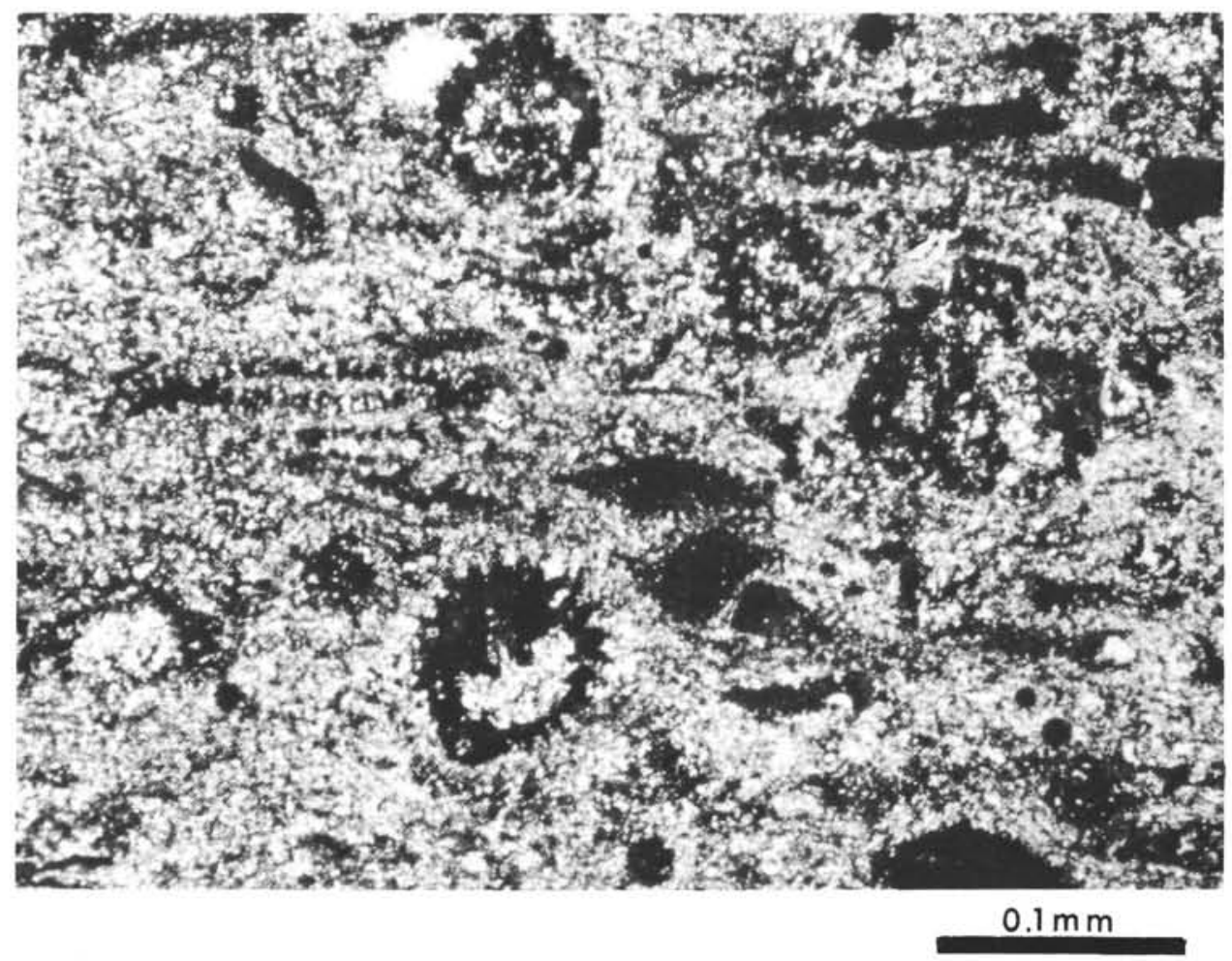

Figure $2 \mathrm{~b}$. Same as above, crossed-nicols. Same radiolarians partially infilled with psuedoisotropic silica which also occurs in the matrix. Many other radiolarians unfilled or only with micrite. 


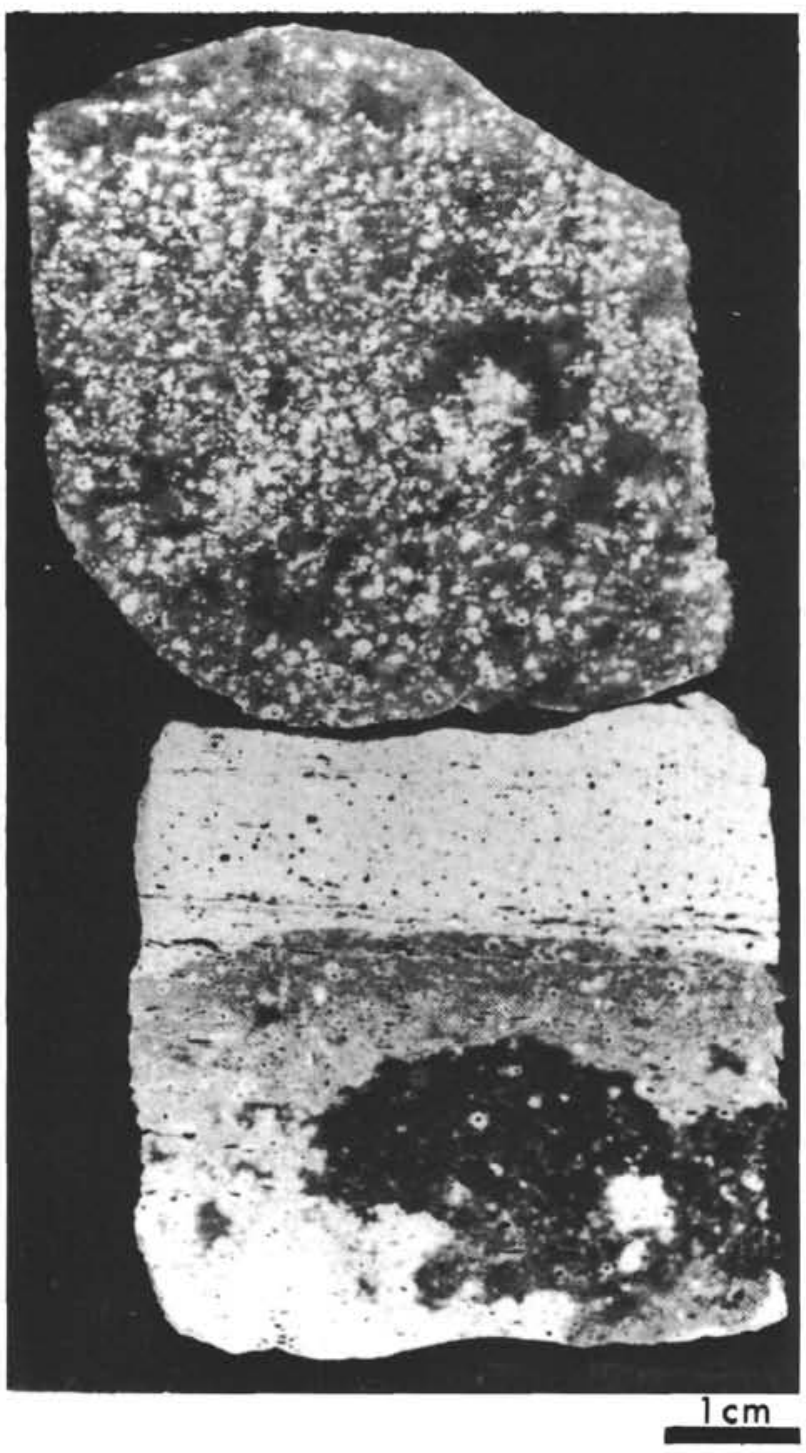

Figure 3. Sample 315A-10-3, 106-115 cm $(736 \mathrm{~m})$, upper Eocene. Example from Unit 3 of silica "fronts" replacing a foraminiferal-nannofossil grainstone. Lower specimen shows a dark reddish-brown (black) silicification "front" with a lighter halo of incompletely silicified grainstone. The matrix in the white portion is also partially replaced, but original laminations are visible. The upper specimen is a reddish-brown chert in which foraminiferal grains are preserved as calcite. The matrix is without traces of nannofossils or siliceous organisms. Laminations are faintly visible.

Some of the quartz veinlets fill displacement fractures, but we noted in a number of instances that quartz veinlets are the result of a dissolution phenomenon. A case thin section from a brecciated chert (Figure 6) illustrates a case in which translucent gray quartz veinlets occur in a reddish-brown chert. A patch of relict, partially silicified white chalk is visible in the center. Note that textural trends do not continue displaced across a veinlet but, in fact, appear terminated, or even compressed.

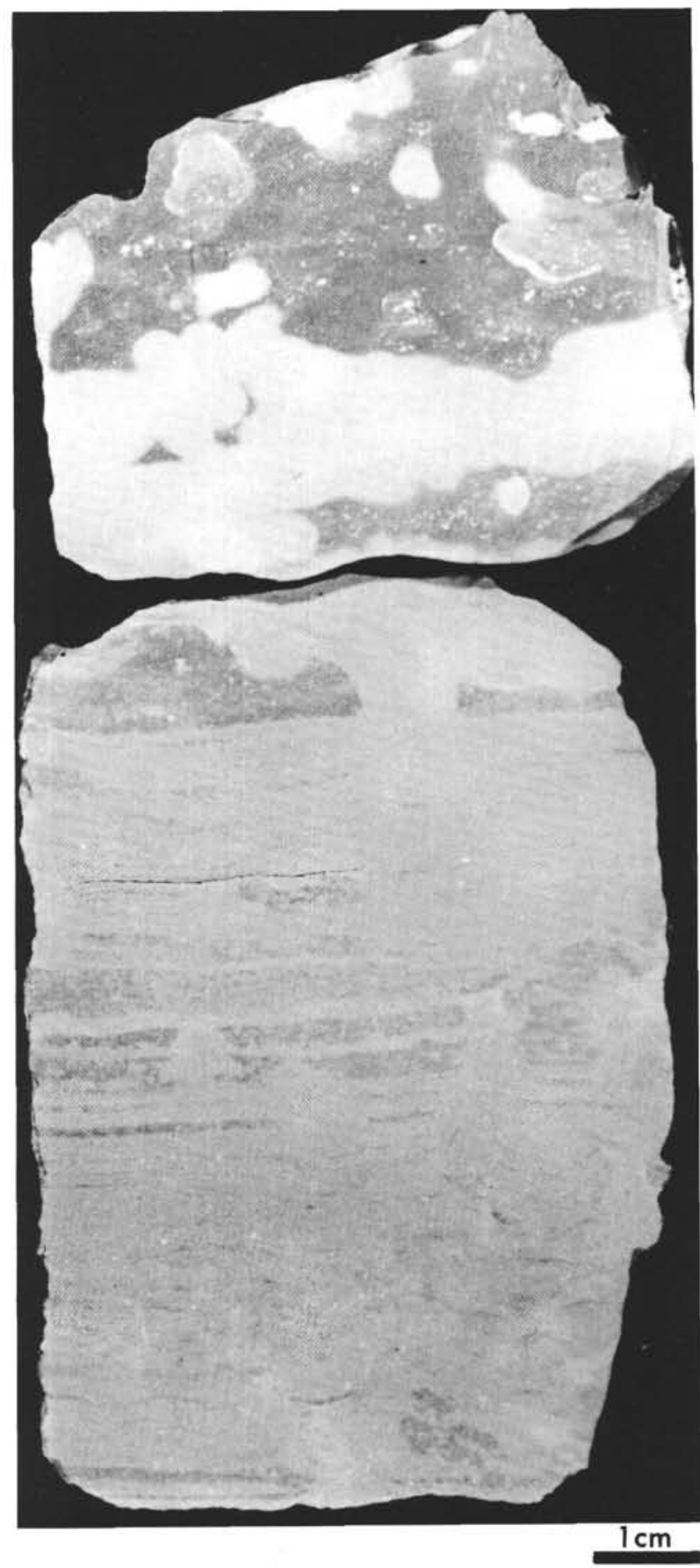

Figure 4. Sample 316-5-2, $128-142 \mathrm{~cm}(450 \mathrm{~m})$, Eocene, Pale brown chert replacing $a$ white nannofossil chalk along laminations reminiscent of redeposited sediment textures. These apparently act as conduits for silicifying solutions which are hindered by some burrow traces visible in the center of the photograph. Scale on the left in $\mathrm{cm}$.

During compaction, pressure solution could promote material transfer and the expulsion of foreign elements such as clay, thus contributing to the formation of pure quartz zones. 


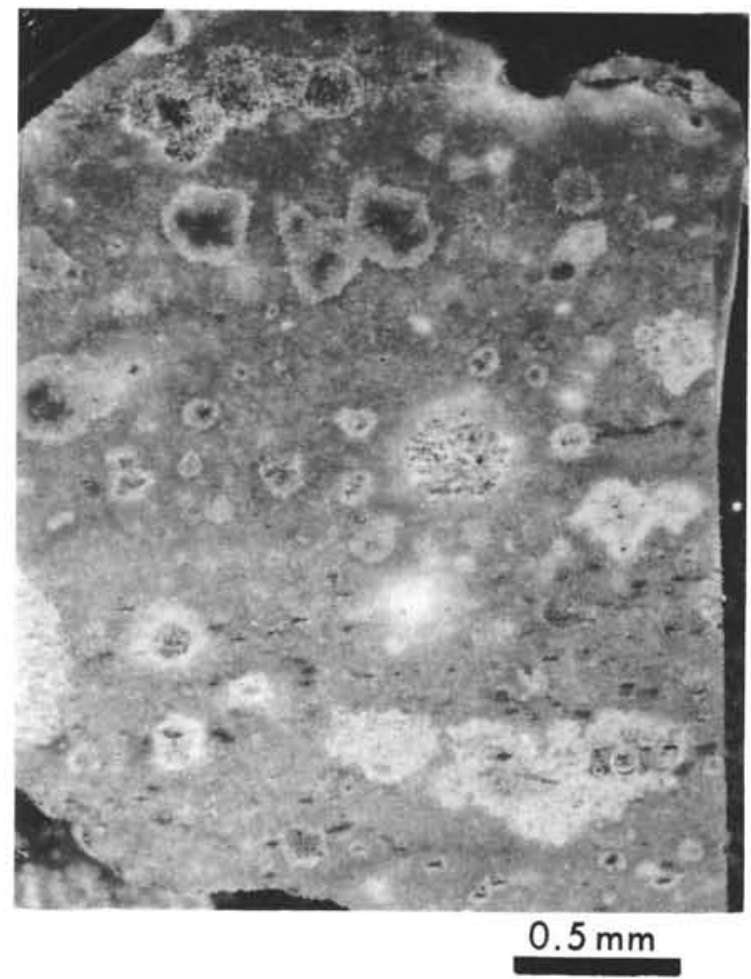

Figure 5. Sample 316-14-1, 146-149 cm (544 m), upperPaleocene. Reddish-orange replacement chert with numerous relict chalk inclusions showing fuzzy contact borders. Some are depleted in silica and calcite resulting in concentrations of earthy iron-oxides. Sample $2 \mathrm{~cm}$ wide, bar scale $=0.5 \mathrm{~mm}$.

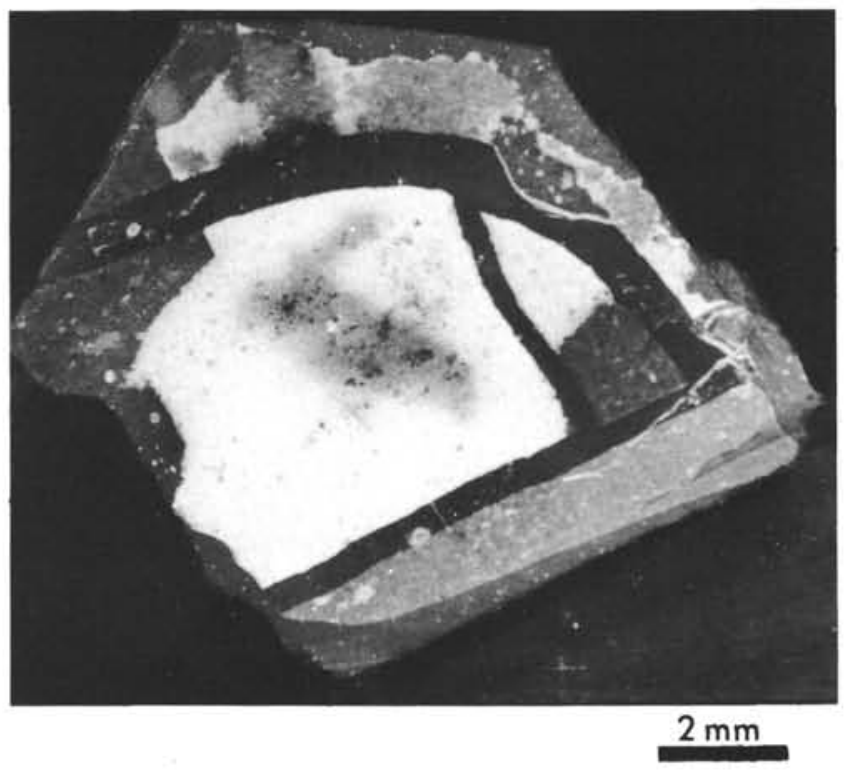

Figure 6. Sample 315A-12-1, 144-150 cm (750 m), Eocene (?). Oblique reflected light micrograph of a thin section of brownish-black to dusky yellow brecciated chert. White center is a partially silicified foram limestone with specks of purple-hued iron-sulfide. The surrounding veinlets are clear chalcedony. Note that textures of the chert and chalk are replaced rather than displaced. Bar scale $=2 \mathrm{~mm}$.

\section{DISCUSSION}

The association of chert with conspicuously redeposited calcareous sediments could have several possible interpretations. (1) These beds may contain a few scattered quartz grains of a certain critical size which might function as favored nucleation centers. The silica phase thus precipitated would also tend to be quartz. (2) Permeability is an important factor in chert formation and redeposited beds have higher permeabilities than the surrounding chalks. Thus, these beds could act as effective conduits for silica-rich solutions. (3) Graded beds deposited by a turbidity current represent a sudden drastic change in the accumulation rate of a deep-sea sediment. Hsü (in press) has discussed the consequences of such an event to the silica diffusion gradient on the sea floor. He envisions that the redeposited layer may trap an anomalously high silica gradient and that the disturbed gradient could be preserved for some time in the sediments. A combination of these factors is possible but more observations are needed. Postulate 3 implies indirectly that chertification takes place early in depositional history. In some pelagic chalks from the southern Alps cherts occur rolled in slump folds. The implication that soft cherts may exist is intriguing, but has not been confirmed by our observations nor any other DSDP report to date. Such folds are possibly sites of preferential chertification, but close inspection usually shows that some chert laminae appear to be sheared, implying that they were brittle during folding. This suggests that some cherts may form early, before significant lithification of calcareous sediments.

Speculations on the age of chert formation abound. Because of the high frequency of chert occurrences in the lower Tertiary, Lancelot (1973) noted that (1) either the marine and sedimentary environments were somehow different at that time, or (2) the formation of chert involves very slow kinetics. An answer is still forthcoming but the excitement about low-latitude Deep Sea Drilling cherts, of which the youngest occurrences are Miocene (Heath, 1973), has caused some authors to overlook the Antarctic diatomites. Weaver and Wise (1972) described a pervasive conversion of pure diatom sediments of probable Pliocene age into a white porcellanite comprising alpha-cristobalite lepispheres. This occurrence is noteworthy because the conversion is apparently without the influence of volcanic sources, clays, or calcite. More attention should be focused on the conditions of this reaction and its paleooceanographic relevance. Similarly, the barite (celestite?) cement in the youngest chert nodule from Site 315 should encourage research on the role of extraneous ions or phases in chert diagenesis.

Although inconclusive, this study supports the tenet of an original cristobalite precursor to the pure quartz phase. In the free-space infilling of calcareous fossil test, once a lepisphere has attained a critical size the reaction kinetics for an inversion to quartz may be accelerated. Likewise, the differences in chert mineralogy between clay-rich and carbonate-rich facies may be due to different maturation rates. Many other factors such as permeability, availability of nucleating grains, local silica supply, and the unknown world of the biological microenvironment in sediments also need to be considered. 


\section{ACKNOWLEDGMENTS}

Many discussions and comments by the scientists aboard Glomar Challenger are greatly appreciated, H. Franz of the ETH Laboratory of Electron Microscopy assisted with the operation of the SEM.

\section{REFERENCES}

Calvert, S.E., 1974. Deposition and diagenesis of silica in marine sediments. In Hsü, K.J. and Jenkyns, H.C. (Eds.), Pelagic sediments: on land and under the sea; Spec. Publ. Int. Assoc. Sedimentol. v. 1, p. 273-299.

Heath, G.R., 1973. Cherts from the Eastern Pacific, Leg 16, Deep Sea Drilling Project. In Van Andel, T.H., Heath, G.R., et al., Initial Reports of the Deep Sea Drilling Project, Volume 16: Washington (U.S. Government Printing Office), p. 609-613.

1974. Dissolved silica and deep-sea sediments. In

Hay, W.H. (Ed.), Studies in paleo-oceanography; Soc. Econ. Pal. Min. Spec. Publ. No. 20, p. 77-94.

Heath, G.R. and Moberly, R., 1971. Cherts from the Western Pacific, Leg 7, Deep Sea Drilling Project. In Winterer, E.L., Riedel, W.R., et al., Initial Reports of the Deep Sea Drilling Project, Volume 7: Washington (U.S. Government Printing Office), p. 991-1007.

Hsü, K.J., in press. Paleooceanography of the Mesozoic Alpine-Tethys. Geol. Soc. Am. Spec. Paper.
Jones, J.B. and Segnit, E.R., 1971. The Nature of opal I. Nomenclature and constituent phases: J. Geol. Soc. Australia, v. 18, p. 57-68.

Lancelot, Y., 1973, Chert and silica diagenesis in sediments from the Central Pacific. In Winterer, E.L., Ewing, J.I., et al., Initial Reports of the Deep Sea Drilling Project, Volume 17: Washington (U.S. Government Printing Office), p. 377-405.

Matter, A., 1974. Burial diagenesis of pelitic and carbonate deep sea sediments from the Arabian Sea. In Whitmarsh, R.B., Ross, D.A., et al., Initial Reports of the Deep Sea Drilling Project, Volume 23: Washington (U.S. Government Printing Office), p. 421-469.

Taliaferro, N.L., 1934. Contraction phenomena in cherts: Geol. Soc. Am. Bull., v. 45, p. 189-232.

Von Rad, U. and Rösch, H., 1974. Petrography and diagenesis of deep-sea cherts from the Central Atlantic. In Hsu, K.J. and Jenkyns, H.C. (Eds.), Pelagic sediments: on land and under the sea: Spec. Publ. Int. Assoc. Sedimentol. v. 1, p. 327-347.

Weaver, F.M. and Wise, S.W., Jr., 1972. Ultramorphology of deep sea cristobalitic chert: Nature Phys. Sci., v. 237, p. 5657.

Wise, S.W., Jr., and Kelts, K. 1972. Inferred diagenetic history of a weakly silicified deep sea chalk: Gulf. Coast Assol. Geol. Soc. Trans., v. 22, p. 177-203.

Wise, S.W., Jr., and Weaver, F.M., 1974. Chertification of oceanic sediments. In Hsü, K.J. and Jenkyns, H.C. (Eds.), Pelagic sediments: on land and under the sea: Spec. Publ. Int. Assoc. Sedimentol., v. 1, p. 301-326. 


\section{PLATE 1}

Sample 315A-10-2, 33-37 cm (733 m), lower Oligocene. Nucleation and incipient development of alpha-cristobalite lepispheres forming on the interior wall of a foraminifer chamber. Sample from a partially silicified, light greenish-gray graded grainstone with scattered rare volcanic grains. Scanning electron micrographs with EDAX analyzer to check compositions.

Figure 1 Seven silica lepispheres within a foram chamber. Wall is lined by a forest of euhedral, blocky secondary calcite crystals and has been partially recrystallized.

Figure 2 Detail of the interior lining of the chamber wall with blocky secondary calcite and both partial $(5 \mu \mathrm{m})$ and fully developed silica lepispheres $(10 \mu \mathrm{m})$. Original foram pores faintly visible near the lower spherules.

Figure 3 Close-up of a lepisphere split through the middle by sample preparation. Flattened side attached to chamber wall. Note the irregular silica phase in the center and the transition to better developed blades.

Figure 4 Detail of the outer surface of a small silica lepisphere. Well-developed blades interpenetrate to form a rosette pattern. Note the typical ragged edges on the blades.

Figure $5 \quad$ Ultramorphology of the outer blade edges from Figure 3. Vermiform or bulbous edges may represent amorphous opal as a first stage in the propagating growth of opal-CT crystals.

Figure $6 \quad$ Ultramorphology of the nucleation center of a lepisphere (see Figure 3). EDAX analysis confirms a silica composition. The irregular morphology of bead strands suggests that this material is a more disordered form of silica than opal-CT; possibly opal-A. Comparison with Figure 3 shows that there is a progressive outward transition to blades showing a better crystal habit. 
PLATE 1
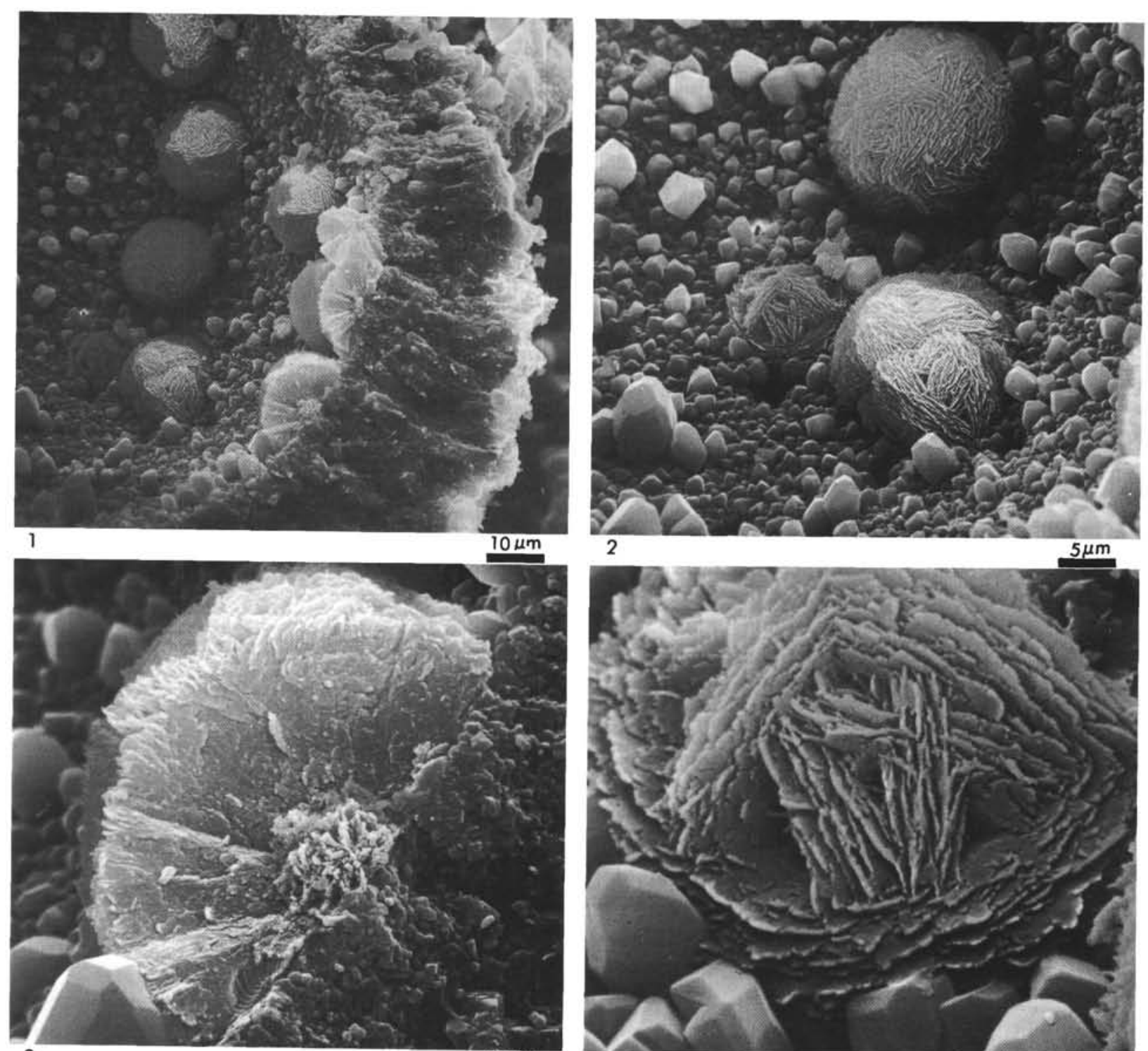

3

$2 \mu \mathrm{m}$
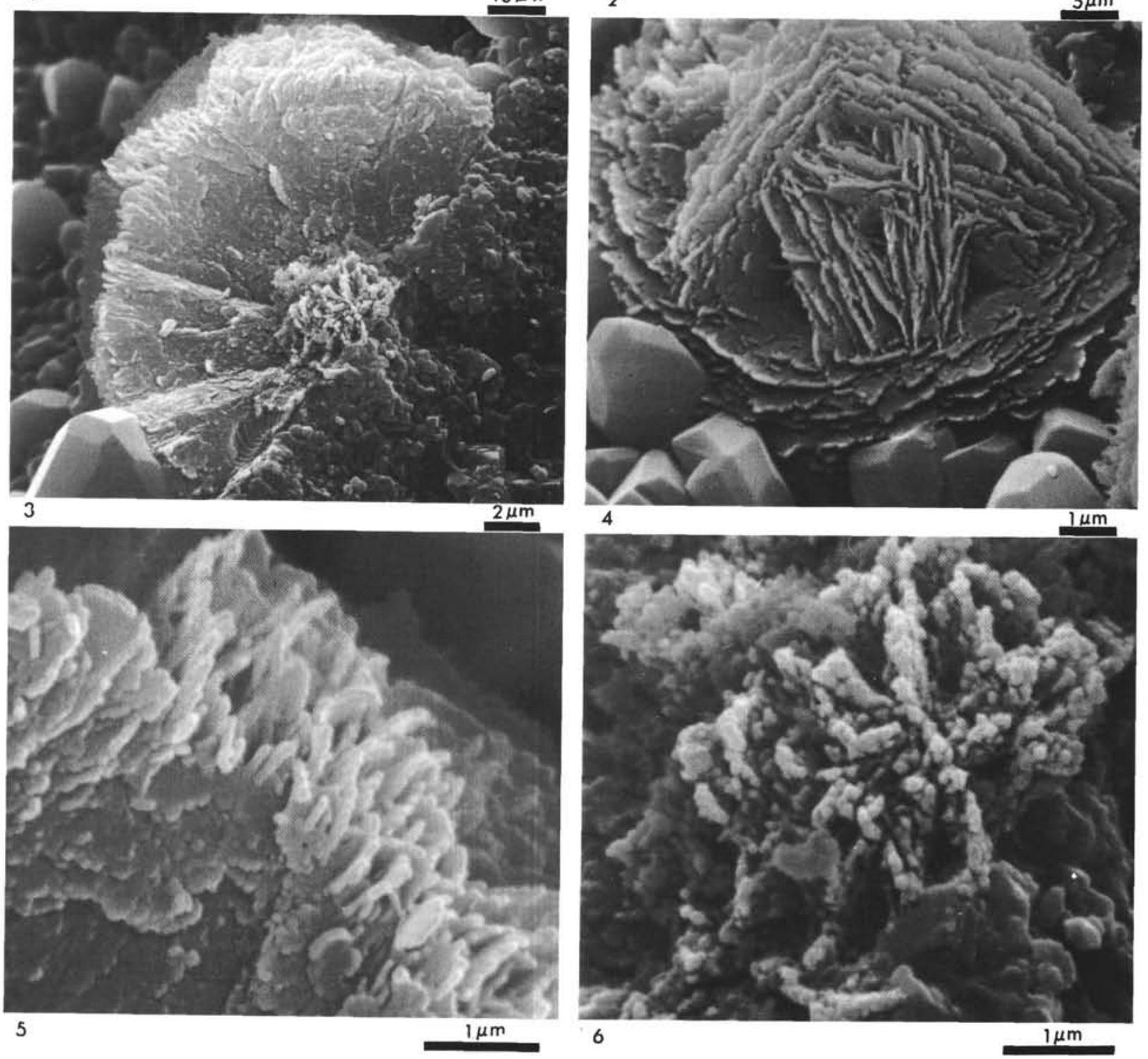